\title{
Guilt, Love, and Forgiveness in David Hare's The Reader and Bernhard Schlink’s Der Vorleser
}

\author{
Naglaa Hassan Abou-Agag \\ Alexandria University, Alexandria, Egypt
}

\begin{abstract}
The paper proposes to investigate feelings of guilt, love, and forgiveness as they manifest themselves in David Hare's The Reader (2009). It will focus on Hare's selection of detail in his screenplay The Reader; a dramatic adaptation of Bernhard Schlink's novel of 1995. This will involve comparing the novel to the dramatic text for the purpose of showing the movement from narrative to dramatic rendering. The paper aspires to reach the conclusion that Hare's screenplay, The Reader creates a world of signification where the interplay of guilt, love, and forgiveness shape the textual and stage space. Read in light of Shoshana Felman's The Juridical Unconscious (2002), the play investigates the traumatic history of Nazi Germany with scope for analysis of guilt and forgiveness and the possibility of atonement through love and literature. The focus of the paper will be on the ideological and formal structure of the play and its impact on meanings and interpretations.
\end{abstract}

Keywords: guilt, David Hare, Shoshana Felman, Nazi Germany, juridical unconscious

\section{Introduction}

David Hare's screenplay The Reader (2009), a dramatic adaptation of Bernhard Schlink's novel Der Vorleser (1995), presents the interplay of guilt, love, and forgiveness within a dramatic world characterized by immediacy and polyphony of voice, as opposed to the past tense narrative dominated by the voice of the narrator and contained by the linear development of events in Schlink's novel. Both novel and play, however, use the same story line and are informed by the same historical background, thus constituting part of what is known as holocaust literature where the traumatic experience of the camps is the focal point around which events and characters evolve.

In both novel and play, young Michael Berg gets involved with an older woman, Hanna Schmitz, to whom he reads works of literature of his choice. The sudden disappearance of Hanna leaves Michael struggling with feelings of grief, guilt, and loneliness and the unexpected reappearance of her at a camp trial revives these feelings and pushes Michael towards a quest for understanding his own feelings, the nature of Hanna's behavior, the motives behind what she has done, the guilt of the camp generation, and the responses of the younger generation. This quest remains unfulfilled till the end of both novel and play, even after Hanna's suicide, which raises questions about the possibility of true forgiveness. In the novel, the events and characters are all seen from the perspective of a Michael in his fifties looking back at his most influential adolescent experience and the linear development of the text leaves little scope for the polyphony of voice apparent in

Naglaa Hassan Abou-Agag, Ph.D., associate professor of drama and comparative literature, Department of English Language and Literature, Faculty of Arts, Alexandria University. 
Hare's screenplay, where Hanna enjoys an independent voice contesting the authoritative voice of Michael that comes from the novel. Therefore, although both novel and play belong to holocaust literature and are about the same experience, they offer different meanings and interpretations.

\section{Holocaust Literature}

The holocaust may be seen as a central event in the history of mankind, the representation of which in literature and cinema has proven essential "for the self-understanding and self-reflection of Western society" (Stern, 2004, p. 193). Between 1946 and 1947, a number of feature films dealing with the holocaust appeared: The Last Station in Poland, The Murderers Are Among Us, The Shadows, The Path is Long, and Morituri in Germany (Stern, 2004, p. 198). More literary works and films were produced over the second half of the 20th century. Among these are Primo Levi’s novel Is This a Man? (1958, Italy), Alain Resnais' documentary Night and Fog (1955, France), Peter Weiss's play The Investigation (1961, Germany), Yoram Kaniuk’s novel Adam Son of a Dog (1969, Israel), Isaac Bashevis Singer's novel Enemies, a Love Story (1973, United States), Orna Ben-Dor's film Because of That War (1988, Israel), Thomas Bernhard's play Heldenplatz/Plaza of Heroes (1988, Austria), Steven Spielberg's film Schindler's List (1993, United States), Istvan Szabo's Sunshine (1999, Canada, Germany, Hungary), and Roman Polanski's The Pianist (2002, Canada, France, Germany, Poland) (Stern, 2004, p. 196).

The story of Michael and Hanna in both novel and play exposes Nazi policies and the brutal practices in the camps. The guilt and shame both characters struggle within the novel and the play raise issues of justice and healing through forgiveness so that the German society would endure and overcome the break that has occurred in both the legal system and the imagination of the German individual. In addition, in both novel and play, the crime of Hanna, representing the crimes of the Nazi, is discussed within the framework of the law, attempting to define the nature of the crime, the responsibility of each one of the defendants, and the suitable punishment. However, as Hanna Arendt writes, the:

Definition of Nazi policy as a crime (“criminal guilt”) strikes (...) (her) as questionable. The Nazi crimes, it seems to (...) (her), explode the limits of the law; and that is precisely what constitutes their monstrousness. For these crimes, no punishment is severe enough... That is, this guilt, in contrast to all criminal guilt, oversteps and shatters any and all legal systems. (quoted in Felman, 2002, p. 138, italics in original)

Focusing on the legal aspect of the holocaust experience would limit the scope of investigation and localize the event. The psychological dimension, the ideological backing, and the moral implications have to come together via a theoretical attempt to understand and evaluate the nature and the consequences of this central event in the history of the West. In Felman's The Juridical Unconscious, the trauma theory is the framework for the analysis of two important trials; the O. J. Simpson Case in The United States of America in 1994-1995 and the Eichmann trial in Jerusalem in 1961. According to Felman (2002), before the Eichmann Trial, "Holocaust survivors did not talk about their past, and when they did, they were not listened to. Their memories were sealed in muteness and in silence” (p. 127). The Eichmann Trial made of survivors' stories "one national, collective story... that formerly existed only in the repressed form of a series of untold, fragmented private stories and traumatic memories” (Felman, 2002, p. 7). Along the same lines, the trial in both novel and play revisits the Nazi era and sets in perspective the history with which the older generation in both texts is burdened. In both novel and play, the trial of Hanna and her colleagues from the Protective Squad (Schutzstaffel) also give scope to the voice of the victims represented by Rose and Ilana Mather, the only two 
survivors of the church fire. The testimony of both mother and daughter, coupled with the book the daughter has written on the incident, exposes Hanna's guilt and creates a dynamic world of action on stage, where interaction between "speaker, addressee, time, [and] location" presents contesting extended messages (Elam, 2002, p. 128), thus turning the trial scene into a "visual event” (Stern, 2004, p. 204).

\section{The Trial in Both Novel and Play}

The trial is the point where Michael is forced to confront his past and to investigate the impact on his life of the brief relationship he had with Hanna when he was a 15-year-old boy. It is also an opportunity to explore the past of the nation and whirl away "the dust that society had permitted to settle over the horrors of the past” (Schlink, 1997, p. 91). On the personal level, the trial scene raises the question of the parents' guilt; they must have all taken part in the Third Reich (Schlink, 1997, p. 92) and revisits the Michael/Hanna relationship. The age difference places Hanna in negative light as a predator exploiting the emotions, the body, and the reading ability of young Michael, in the same way she exercises power over the inmates at the camp. There is also Michael's sense of shame at developing a relationship with an older woman; something that he cannot tell, neither to his family nor to his friends. Feelings of guilt and grief overwhelm him when she suddenly disappears and are resurrected with a kind of anxiety when he sees her at the trial. The possibility of forgiveness is toyed with throughout both texts, with Hanna asking Michael in her will, after committing suicide, to give the money she has saved to the daughter who wrote the book which has drawn attention to the case of the women who burnt to death in the church while the defendants, Hanna included, were in charge.

Furthermore, the trial is the point at which Hanna's shame is brought into the light. Her being illiterate has always been a major problem she has been trying to deal with in secret. She refuses a promotion in the tram company because this would entail reading and writing and she gets extremely nervous when Michael goes out during their trip together to bring her breakfast and a flower assuming that she will read the note he has left her. She is even willing to be condemned for something she has not done so that her secret would not be exposed. It seems that her shame for being illiterate is much bigger than her shame for being an SS guard who knew about and took part in the process of sending women to Auschwitz to be killed and under whose watch hundreds of women burnt to death. This raises the question of whether she is aware of the atrocities she has committed and whether her cruelty finds its origin in her ignorance. Hanna's illiteracy is "a moral deficit or ethical obtuseness on the part of the German generation that, despite its veneer of civility, enacted, or at least condoned, the vilest brutality” (Worthington, 2011, p. 207) seen in modern history in the West. Hanna's confusion and her inability to realize the monstrosity of her crime, which may find its origin in her illiteracy, is translated into the question she addresses either to the judge, to herself, to the people at the court, or to the readers/audience, and which remains hanging in the screenplay:

HANNA

Well, what would you have done?

HANNA is looking at the JUDGE—a perfectly straight question. MICHAEL smiles slightly, proud of her. Everyone in the court waits for the JUDGE to answer. Silence. ROHL is impassive. But HANNA follows her own thoughts. She quietly asks herself a question.

HANNA

So should I never have signed up at Siemens? (Hare, 2009, p. 62) 
This challenges the reply the judge provides in the novel when he says: "There are matters one simply cannot get drawn into, that one must distance oneself from, if the price is not life and limb” (Schlink, 1997, p. 112). The hanging question in the screenplay gives scope to as many different answers as possible, placing the issue of Hanna's guilt at center stage; in contrast to the novel where the narrator, Michael, is preoccupied with the analysis of his own feeling of guilt towards Hanna when he disowns her at the club where he was swimming with his school friends:

My body yearned for Hanna. But even worse than my physical desire was my sense of guilt. Why hadn't I jumped up immediately when she stood there and run to her. (Schlink, 1997, p. 83)

He later dwells upon the same issue when he examines his feelings of guilt:

However, the fact that I had not driven her away did not change the fact that I had betrayed her. So I was still guilty. And if I was not guilty because one cannot be guilty of betraying a criminal, then I was guilty of having loved a criminal. (Schlink, 1997, p. 134)

In the screenplay, Hanna's imagination is free from the constraints imposed upon it in Michael's narrative, since she achieves a separate physical presence and therefore, acquires an independent voice. This allows her to raise the question of whether or not she should have "signed up at Siemens" (Hare, 2009, p. 62), a question that marks the beginning of a long journey of self-discovery and soul-searching.

\section{Narrative Techniques Versus the Dramatic World}

Hanna's narrative in Schlink's novel is contained within the master narrative of Michael, as his voice dominates the narration and his perspective on events imposes restrictions on all the stories he presents. The novel focuses on "Michael [who] needs to understand (...) But the incomprehensible gaps in the text repeatedly undermine his attempts at explanation or narrative authority” (Worthington, 2011, p. 218), providing at no time “access to Hanna's interiority” (Worthington, 2011, p. 212). The novel begins with "(w)hen I was fifteen, I got hepatitis. It started in the fall and lasted until spring. As the year darkened and turned colder, I got weaker and weaker" (Hare, 2009, p. 3). It ends with:

As soon as I returned from New York, I donated Hanna's money in her name to the Jewish League Against Illiteracy. I received a short, computer-generated letter in which the Jewish League thanked Ms. Hanna Schmitz for her donation. With the letter in my pocket, I drove to the cemetery, to Hanna's grave. It was the first and only time I stood there. (Hare, 2009, p. 218)

The dominance of the first person narrator in the novel from beginning to end, together with the past tense narrative form a rigid framework within which characters, actions, and emotions are presented.

The screenplay The Reader, on the other hand, creates a world of signification where the interplay of guilt, love, and forgiveness shapes the textual and stage space and challenges the authority of Schlink's text. In fact, Hare's The Reader fits the definition of dramatic worlds according to Elam (2002), which "are revealed through the persons, actions and statements which make them up, and not through external commentary” (p. 101). In Hare's screenplay, the authoritative voice of Michael, that comes from the novel is broken down to three separate and contesting voices: Michael the teenager, Michael the university student, and Michael the 51-year old divorcee, who has been reading for Hanna examples of Western literature on tape and sending the tapes to her in prison, not knowing that she uses the tapes to learn to read and write. Each of the three separate Michael 
voices presents its own narrative and functions in its own dramatic space, thus deconstructing the uniformity of the dominant narrative voice in Schlink's novel.

In addition, Hanna in the screenplay is not portrayed through Michael's voice and therefore gains independence. This explains the powerful physical presence of Hanna, which is described in the play as follows:

She picks up one, rolls it, smoothes it over her calf and knee, then attaches it to her suspender. She reaches for the other. The flesh is bare between her legs. MICHAEL watches, riveted. HANNA seems oblivious. But as she is about to put the second stocking on, she looks at him. She drops her dress, and straightens, holding her stare. In response, he blushes, then panic and runs out of the flat. The door slams. (Hare, 2009, p. 9)

During the trial, Hanna is again presented as a most dominant physical presence when she comes into the court room with the rest of the defendants:

HANNA and the PRISONERS are led into the court. HANNA'S suit is so formal that members of the public call out. “Nazi! Nazi!” DIETER leans in to MARTHE. HANNA walks on to her place. (Hare, 2009, p. 80)

Her appearance stirs a reaction in the court among the people attending as well as the law students who are watching the trial as part of a special seminar group on The Legal System in the Third Reich. In addition to the way she looks at the court, Hanna's long conversation with the judge (Hare, 2009, pp. 70-74) does not only assert her independent physical existence in space and time but also shows a mind acting on its own and a personality free from the constraints of the imagination of a narrator. Hence, the screenplay creates a dramatic world where action unfolds in space and time due to the interaction between individual and independent characters on stage.

Another aspect of Hare's The Reader, which creates the immediacy of the dramatic world and hence the distance between the three periods of time the events occupy as everything "that happens in a screenplay happens in the moment” (Boon, 2008), is the continuous shift from 1995 to 1958 and to the 1960s. The organization of scene slugs at the beginning of Hare's screenplay is a case in point. This provides the temporal structure of the play as opposed to the "(c)hronological time which belongs to the fibula of the drama” (Elam, 2002, p. 106). In the novel both fibula and narrative follow the same organization of events with Michael's voice as a 51-year old lawyer opening and ending the novel. Conversely, in the screenplay the independence of all the voices presented in the screenplay: Hanna's voice and the three contesting Michael voices is created and sustained through 'the absence of narratorial guides, (which provides) external description and 'world-creating' possibilities, the dramatic world has to be specified from within by means of references made to it by the very individuals who constitute it" (Elam, 2002, p. 100).

Finally, contrary to the novel, where only the titles of the literary works Michael reads to Hanna are mentioned, Hare's screenplay gives space to extracts from these works to be included in the text of the play and to occupy part of the dramatic space. The literary works Michael chooses for Hanna represent the essence of Western culture and the Humanist tradition, against which the crimes of the Nazi are symbolically committed. It is true that individuals suffered and died as a result of the Nazi crimes but the impact of these crimes is far reaching and they may be considered a violation of the Humanist tradition upon which Western civilization is based. Hence the extracts incorporated in the play further accentuate Hanna's crime, by placing it against the power of literature. Ironically the tapes educate Hanna literally. This establishes the Western canon as the carrier of universal human values. Thus, intertextuality is used in the play to sustain the continuity of Western culture and the power of literature, to remember Arnold's (1987) words about poetry, to “interpret life for us, to 
console us, to sustain us” (p. 260). The assumption created in both novel and play is that Hanna's literacy grants her knowledge and nurtures her sense of guilt and remorse which is translated into the will she writes in which she leaves all the money she has been saving to the daughter who wrote the book to use in whatever way she sees fit. The will may also be an act of seeking forgiveness, not necessarily from the daughter herself, but on a more philosophical level as Kim L. Worthington states that "-at least (...)-her unforgivable crime, perhaps the crime of Nazi Germany itself, calls for forgiveness” (p. 218, italics in original).

Intertextuality in the screen play is also achieved with regard to the relation between the novel and the screenplay, with the novel exercising control over the play in some instants and the play defying the novel in others. In the novel there are images of Hanna that have been fixed in the imagination of Michael and that have shaped his subsequent relationships with women (Schlink, 1997, pp. 62, 64, 80). In the screenplay, these fixed haunting images are not accentuated and the distance the dramatic world creates between Hanna and Michael breaks the power of Michael's narrative voice in the novel.

\section{Conclusions}

Though both Schlink's novel and Hare's screenplay are centered on the same story line, the novel is preoccupied with Michael, his guilt for loving a Nazi criminal, for loving an older woman, and for betraying her at some point; his attempts to understand what she has done; and his exploration of the possibility of forgiveness. The screenplay, on the other hand, places all the characters on equal footing in dramatic space and presents the action as it takes place in the here and now of the dramatic world with no psychological analysis and no guiding narratorial voice. Therefore, Hanna achieves an existence away from Michael's imagination that dominates the novel. She is allowed a separate voice not contained by the narrator and Hare's screenplay, thus, presents an angle to Holocaust literature that gives scope to the point of view of the guards.

\section{References}

Arnold, M. (1987). The study of poetry. In D. J. Enright, \& E. De Chickera (Eds.), English critical texts (pp. 260-285). Oxford: Clarendon Press.

Boon, K. A. (2008). The screenplay, imagism, and modern aesthetics. Literature/Film Quarterly, 36(4). Retrieved from http://www.questia.com/read/1P3-1592024251/the-screenplay-imagism-and-modern-aesthetics

Elam, K. (2002). The semiotics of theatre and drama (2nd ed.). London: Routledge.

Felman, S. (2002). The political unconscious: Trials and traumas in the twentieth century. Cambridge: Harvard University Press.

Hare, D. (2009). The reader. New York: Weinstein Books.

Schlink, B. (1995). Der Vorleser (The reader). (C. B. Janeway, Trans.). New York: Vintage Books.

Stern, F. (2004). The holocaust: Representing lasting images in film and literature. In J. Matthaus (Ed.), Contemporary responses to the holocaust (pp.193-218). Westport, CT: Praeger.

Worthington, K. L. (2011). Suturing the wound: Derrida’s “On forgiveness' and Schlink’s The Reader”. Comparative Literature, 63(3), 203-224. 